\title{
Decreased metastatic spread in mice homozygous for a null allele of the cystatin $\mathrm{C}$ protease inhibitor
} gene

C-G Huh, K Håkansson, C-M Nathanson, U P Thorgeirsson, N Jonsson, A Grubb, M Abrahamson, S Karlsson

\begin{abstract}
Aims-Increased or altered activities of cysteine proteases have been implicated in serious human disorders such as cancer, rheumatoid arthritis, sepsis, and osteoporosis. To improve the current knowledge of the regulatory role of a major mammalian cysteine protease inhibitor, cystatin $C$, in such disease processes, a cystatin $\mathbf{C}$ deficient mouse was generated and characterised.
\end{abstract}

Methods-The mouse cystatin $\mathrm{C}$ gene was inactivated by insertion of a bacterial neo gene through homologous recombination in $129 / \mathrm{Sv}$ embryonic stem cells. Embryonic stem cell clones were injected into C57BL/6J blastocysts followed by injection of the blastocysts into pseudopregnant female mice. F1 offspring with agouti coat colour after mating of chimaeric males with C57BL/6J females were examined by DNA analysis, and mice carrying the targeted mutation were intercrossed to obtain homozygous cystatin $\mathrm{C}$ deficient $\left(\mathrm{CysC}^{-1-}\right)$ mice. To study the role of cysteine proteases and their inhibitors in metastasis, the spread of B16-F10 melanoma cells in $\mathrm{CysC}^{-/-}$and wild-type mice was compared. Analysis of the formation of remote metastases was carried out by intravenous injection of $\beta$-galactosidase transfected B16-F10 cells and subseqent determination of cancer cell colonies in the lungs.

Results-Cystatin C deficient mice were fertile and showed no gross pathological abnormality up to 6 months of age. Compared with wild-type mice, seven times fewer large metastatic colonies were counted by means of a dissecting microscope in $\mathrm{CysC}^{-/-}$mice two weeks after tail vein injection of $\mathrm{B} 16-\mathrm{F} 10$ cells. At all of eight time points from 15 minutes to two weeks after intravenous injection of tumour cells, the $\mathrm{CysC}^{-1-}$ mice had significantly fewer lung metastases. The observed differences were smaller when $\beta$-galactosidase transfected cells were used to allow counting of small colonies. Subcutanous and intracerebral tumour growth was not different in the $\mathrm{CysC}^{-/-}$ mice.

Conclusions-Cystatin C concentrations in vivo might influence metastasis in some tissues. The decreased metastatic spread of $\mathrm{B} 16-\mathrm{F} 10$ cells in $\mathrm{CysC}^{-1-}$ mice is the result of both reduced seeding and reduced growth of tumour cells in their lungs.

(F Clin Pathol: Mol Pathol 1999;52:332-340)

Keywords: cystatin C; cysteine protease inhibitor; knockout mouse; metastasis

The cystatins constitute a superfamily of cysteine protease inhibitors. ${ }^{12}$ Cystatin C belongs to family 2 of this superfamily and is a potent inhibitor of cathepsins $\mathrm{B}, \mathrm{H}, \mathrm{L}$, and $\mathrm{S}$. It is a secreted protein and its major functional site is presumed to be extracellular. Mature cystatin C is composed of 120 amino acid residues in a single polypeptide chain with two intrachain disulphide bonds. The promoter regions of the human and mouse cystatin $\mathrm{C}$ genes resemble the promoters of "housekeeping" genes, indicating a non-tissue specific pattern of gene expression. ${ }^{3}{ }^{4}$ Indeed, cystatin $\mathrm{C}$ is present in virtually all mammalian tissues, although the inhibitor is found at particularly high concentrations in the cerebrospinal fluid of the central nervous system (CNS). ${ }^{5}$

In vitro experiments have indicated that cystatins have a broad spectrum of biological roles, in processes ranging from bone resorption, ${ }^{67}$ processing of certain prohormones, ${ }^{8}$ modulation of neutrophil chemotactic activity and inflammation,,${ }^{90}$ and resistance to a range of bacterial ${ }^{11}$ and viral ${ }^{12-14}$ infections. Cysteine proteases of certain parasitic protozoa ${ }^{15}$ could be another target for cystatin inhibition. In the case of cystatin C, specifically, we have shown previously that parathyroid hormone stimulated bone resorption ${ }^{77}$ and replication of herpes simplex virus and human coronavirus in cell culture ${ }^{18}{ }^{19}$ is effectively inhibited by physiological concentrations of recombinant human cystatin C.

Although the in vivo role of cystatin $\mathrm{C}$ has not yet been established, it is known that a point mutation in the human cystatin $\mathrm{C}$ gene resulting in a Leu $\rightarrow$ Gln substitution of residue 68 leads to the lethal autosomal dominant disease, hereditary cystatin $\mathrm{C}$ amyloid angiopathy (HCCAA). ${ }^{20-22}$ The human cystatin $\mathrm{C}$ gene is located on chromosome 20 and contains three exons. ${ }^{23}$ Carriers of the Leu68 $\rightarrow$ Gln mutation live a normal life until the start of repeated and massive brain haemorrhages, which normally occur at the age of 30-35, as a result of the deposition of the mutant protein in the walls of the cerebral arteries. Recently, it has also been shown that mutations in the human cystatin B gene, caus-
Accepted for publication 1 July 1999 
ing a decreased production of the intracellular family 1 cystatin, cystatin B (also called stefin B), lead to progressive myoclonus epilepsy. ${ }^{24}$

The cystatin protein superfamily comprises natural inhibitors of cysteine proteases, which have been implicated in proteolytic tissue degradation during tumour invasion and metastatic development (reviewed by Sloane and colleagues $^{25}$ ). Cathepsins B and L can degrade the major structural components of basement membrane, laminin, and type IV collagen, and both these enzymes have been associated with malignancy. Plasma membrane associated cathepsin B is raised in human and rodent tumour cells. ${ }^{25-27}$ In metastatic ras transformed cells, concentrations of cathepsins B and L were increased and the activity of their endogenous inhibitors, the cystatins, was decreased. ${ }^{28} 29$

In an effort to clarify the physiological and pathophysiological roles of cystatin C, we have generated mice devoid of functional cystatin $\mathrm{C}$ genes and used them to elucidate the role of this cysteine protease inhibitor in metastatic development.

\section{Methods}

Restriction enzymes and DNA modifying enzymes were obtained from Stratagene (La Jolla, California, USA). $\left[{ }^{32} \mathrm{P}\right] \mathrm{dCTP}(3000 \mathrm{Ci} /$ $\mathrm{mmol}$ ) was from Amersham (Arlington, Illinois, USA). All nucleic acid manipulations, including Southern blotting, northern blotting, and the polymerase chain reaction (PCR), were carried out according to standard procedures. ${ }^{30}$ Embryo manipulation and generation of chimaeric mice were done as described previously. ${ }^{31}$ The CCE embryonic stem cell line was a gift from EJ Robertson (Harvard University, Massachusetts, USA). The mouse strain, C57BL/6J, was purchased from Jackson Laboratories, Bar Harbor, Maine, USA. All the animals used in the experiments were handled properly and approved protocols were followed, in accordance with the "NIH guide to the care and use of laboratory animals".

CONSTRUCTION OF GENE TARGETING VECTOR

A replacement type of gene targeting vector was constructed by the following steps: (1) A genomic $9.5 \mathrm{~kb}$ NotI-XbaI DNA segment isolated from a library made from mouse strain $129 / \mathrm{Sv}^{4}$ was cloned into the plasmid vector pBluescript KS (Stratagene, La Jolla, California, USA). The NotI site is from the multiple cloning site of the lambda fix II vector and is not present in the corresponding site in the mouse genome. The $\mathrm{XbaI}$ site is located in the third exon of the mouse cystatin $\mathrm{C}$ gene. This DNA segment covers the main part of the cystatin $\mathrm{C}$ gene, including the 5 ' sequence upstream of the promoter, the promoter region, exon 1, exon 2, and part of exon 3 (fig 1A). (2) A $1.3 \mathrm{~kb}$ SacI fragment covering the last four codons of the first exon and the first two thirds of the first intron was deleted and replaced by a PGK-neo cassette. The PGKneo cassette was from the plasmid $\mathrm{pKJ} 1 .^{32} \mathrm{~A}$ EcoRI-HindIII fragment from $\mathrm{pKJ} 1$ was cut out, the HindIII site was ligated to a SalI linker, and the fragment was thereafter cloned into an EcoRI-SalI cleaved plasmid, pGEM7, resulting in a plasmid named pGEM7(KJ1). To generate SacI sites on both ends of the PGK-neo cassette, the plasmid pGEM7(KJ1) was cut with EcoRI-NsiI and a $1.8 \mathrm{~kb}$ fragment containing the PGK-neo cassette was cloned between the EcoRI and NsiI sites of pGEM9. The SacI-SacI fragment containing the PGKneo cassette was excised from this plasmid and cloned into the mouse cystatin $\mathrm{C}$ gene, to replace the earlier deleted $1.3 \mathrm{~kb}$ fragment. The PGK-neo cassette was inserted in the same transcriptional direction as the endogenous mouse cystatin $\mathrm{C}$ gene, as verified by PCR experiments and DNA sequencing (see below). (3) A $0.2 \mathrm{~kb}$ NcoI-EcoRI fragment, covering the remaining first exon from the point just upstream of the ATG translation initiation codon to just before the PGK promoter, was deleted and replaced by a $0.7 \mathrm{~kb}$ NcoIEcoRI fragment of the HCCAA related human mutant cystatin C cDNA. ${ }^{21}{ }^{22}$ Because corresponding NcoI sites are present just upstream of the ATG initiation site, both in the mouse gene and human cystatin $\mathrm{C}$ cDNA, these were used as the upstream fusion point. The inserted cDNA contains the point mutation found in patients with HCCAA, which results in a substitution of glutamine for leucine at amino acid position 68 of the mature protein. It also has a $3^{\prime}$ poly(A) signal, AATAAA. (4) Finally, to allow for negative selection, a PGK driven herpes simplex virus thymidine kinase gene (PGK-TK) was added at the end of the long $5^{\prime}$ arm of the targeting construct. This construct was designated pTG-6. A unique ClaI site located at the 3' end of the short arm was used to linearise the vector for electroporation.

EMBRYONIC STEM CELL CULTURE, TRANSFECTION, AND SELECTION

The CCE embryonic stem cell line (derived from the $129 / \mathrm{Sv}$ mouse strain) was cultured on a monolayer of mitomycin C treated STO feeder cells, as described previously. ${ }^{33}$ The embryonic stem cell culture medium was Dulbecco's modified Eagle medium supplemented with $10 \%$ fetal bovine serum (HyClone, Logan, Utah, USA) and 10\% newborn calf serum (Gibco/BRL, Gaithersbury, Maryland, USA). Recombinant leukaemia inhibitory factor (LIF) (ESGRO; Gibco) was added to the media, at a concentration of $1000 \mathrm{U} / \mathrm{ml}$, during the entire embryonic stem cell culture time. For transfection, embryonic stem cells were grown to $70 \%$ confluency, trypsinised, and resuspended in phosphate buffered saline (PBS; calcium and magnesium free) at $10^{7}$ cells $/ \mathrm{ml}$. A $20 \mu \mathrm{g}$ aliquot of targeting vector, pTG-6, linearised at the $3^{\prime}$ end by ClaI restriction enzyme cleavage, was mixed with $0.8 \mathrm{ml}$ of cell suspension and electroporated at $240 \mathrm{~V}$ and $500 \mu \mathrm{F}$ (Biorad GenePulser, Biorad, Hercules, California, USA). The cells were transferred to two $10 \mathrm{~cm}$ petri dishes containing fresh feeder cells. Selection was applied after 24 hours with $250 \mu \mathrm{g} / \mathrm{ml} \mathrm{G} 418$ (geneticin; Gibco) and $2 \mu \mathrm{M}$ gancyclovir. The cells were grown for eight 
A

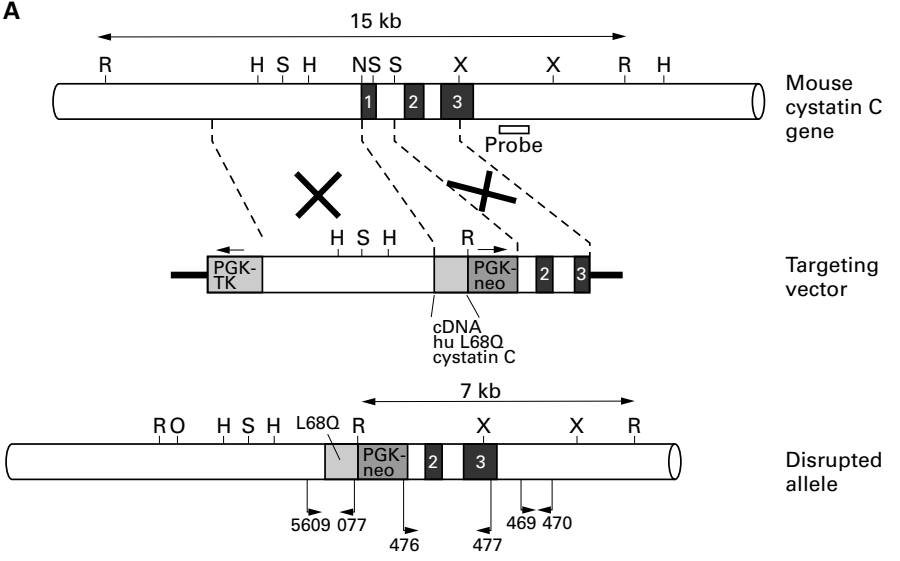

B

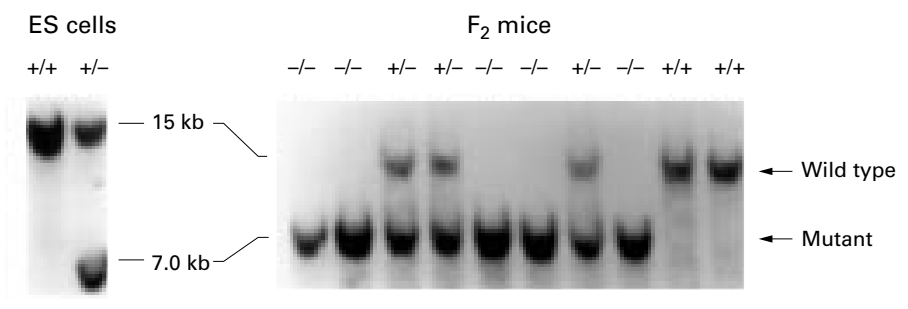

Figure 1 Targeted disruption of the cystatin $C$ locus and germ line transmission of the targeted allele. (A) Schematic diagram of the mouse cystatin $C$ gene (top), the targeting vector pTG-6 (middle), and the targeted cystatin $C$ gene (bottom). The indicated $3^{\prime}$ probe is a $0.9 \mathrm{~kb}$ PCR amplified fragment outside the $3^{\prime}$ end of the mouse cystatin $C$ gene. The three exons are marked by numbers 1,2, and 3. Restriction endonuclease sites are marked for R (EcoRI), H (HindIII), S (SacI), N (NcoI), O (NotI), and X (XbaI). The

"knockin" targeting construct contains a human cDNA encoding L68Q cystatin $C$ (hatched box) and a neomycin resistance cassette. The hypothetical homologous recombination sites are indicated by the cross signs. The sizes of the expected wild-type and disrupted DNA fragments after EcoRI cleavage are indicated. The location of primers used for PCR experiments are indicated with arrows below the scheme of the disrupted allele, with numerical designations relating to their sequences given under experimental procedures. (B) Southern blot analysis of $10 \mu \mathrm{g}$ EcoRI digested DNA from embryonic stem cells and offspring of heterozygote matings, probed with the 3' probe from the genomic DNA. The hybridising fragments from the wild-type and mutant alleles are indicated by the arrows. The cystatin C genotypes are shown on the top: homozygous mutant, -1-; heterozygous, $+/-$; and wild-type, $+/+$ (see text).

additional days with daily medium changes and surviving colonies were picked, expanded, and examined by Southern blot analysis.

SOUTHERN BLOT AND NORTHERN BLOT ANALYSIS Genomic DNA from the surviving clones was isolated as described previously. ${ }^{34}$ DNA was digested with EcoRI and subjected to Southern blot analysis. The probe used to detect homologous recombination was a $0.9 \mathrm{~kb}$ PCR amplified fragment corresponding to a segment downstream from the $3^{\prime}$ end of the mouse cystatin C gene (fig 1A). The forward and reverse primers to amplify the probe had the sequences 5'-ATGGGG TGACAGGGATACTCC CAGCCCTT-3' (469) and 5'CCACATGGTCCCATGGC TTTGGG GAAGAT-3' (470), respectively. Total RNA was extracted from mouse tissues with a commercially available reagent (RNA STAT-60; Tel-test Inc, Texas, USA), as directed by the manufacturer. Human brain RNA was purchased from Clontech (Palo Alto, California,
USA). Total RNA samples $(20 \mu \mathrm{g})$ were examined by northern blot analysis using either mouse cystatin $\mathrm{C}$ cDNA or human cystatin $\mathrm{C}$ cDNA as probes. The filters (Hyclone $\mathrm{N}$; Amersham) were hybridised with the indicated ${ }^{32} \mathrm{P}$ labelled probes $(\sim 106 \mathrm{counts} / \mathrm{min} / \mathrm{ml})$ for 16 hours at $67^{\circ} \mathrm{C}$ in $0.1 \%$ sodium dodecyl sulphate (SDS) $/ 6 \times$ saline sodium citrate (SSC) and washed with $0.1 \% \mathrm{SDS} / 0.1 \times \mathrm{SSC}$ at $67^{\circ} \mathrm{C}$ for 60 minutes.

GENERATION OF HOMOZYGOUS MICE

Mice were housed in a double barrier facility and maintained in a 12 hour light/12 hour dark cycle, with the light cycle starting at 06:00 hours. Correctly targeted embryonic stem cell clones were expanded and approximately 15-20 cells were injected into each 3.5 day old blastocyst from $\mathrm{C} 57 \mathrm{BL} / 6 \mathrm{~J}$ mice, as described previously. ${ }^{31}$ About eight to 10 injected blastocysts were transferred into a single uterine horn of C57BL/DBA F1 pseudopregnant recipients (2.5 days post coitum). Chimaerism was determined visually by the agouti coat colour and male chimaeras with more than $50 \%$ chimaerism were mated with $\mathrm{C} 57 \mathrm{BL} / 6 \mathrm{~J}$ females. The cystatin $\mathrm{C}$ gene locus of F1 offspring with agouti coat colour were examined by Southern blot analysis of tail DNA, and mice carrying the targeted mutation were intercrossed with each other to obtain homozygotes. Siblings of the F1 offspring and their progeny with the wild-type cystatin $\mathrm{C}$ gene were used as control mice.

PCR BASED ANALYSIS OF DNA CONSTRUCTS AND GENOMIC DNA FROM MICE

DNA was extracted from whole blood ${ }^{35}$ drawn from the mutant cystatin $\mathrm{C}$ mice. To study the integrity of the pTG- 6 derived insert in the mice, and to verify a correct homologous recombination in the homozygous mutant cystatin C mice studied, PCR amplifications of informative segments in the cystatin $\mathrm{C}$ gene region were performed. One PCR aiming at confirmation of correct ligation and nucleotide sequence of the human cystatin $\mathrm{C}$ cDNA insert was performed with upstream primer 5609 (5'ACTAGCAGCTGACTGAAGCAGAGG-3'), corresponding to a segment in the mouse cystatin $\mathrm{C}$ promoter, and downstream primer 077 (5'-TCACCTCTTATGCA CACCTCC$\left.3^{\prime}\right)$, complementary to a segment in the 3 ' noncoding sequence of the human cystatin $\mathrm{C}$ cDNA (fig 1A). The reaction was performed in a total volume of $100 \mu \mathrm{l}$ with $1 \mu \mathrm{g}$ genomic template DNA, $0.6 \mu \mathrm{M}$ of each primer, $1.5 \mathrm{U}$ of Ampli Taq Gold polymerase (Perkin Elmer, Roche Molecular Systems, Branchburg, New Jersey, USA), and 2\% (vol/vol) DMSO added in addition to the buffer components and nucleotides recommended by the supplier. The reaction conditions consisted of a preincubation for 12 minutes at $94^{\circ} \mathrm{C}$, followed by 30 cycles of 30 seconds at $94^{\circ} \mathrm{C}, 15$ seconds at $58^{\circ} \mathrm{C}$, and one minute at $72^{\circ} \mathrm{C}$, with a final incubation at $72^{\circ} \mathrm{C}$ for 12 minutes in a Perkin Elmer 2400 Thermal Cycler (Perkin Elmer, Applied Biosystems, Foster City, California, USA). A second segment for analysis of the 
cystatin $\mathrm{C}$ gene region in the mice was amplified for confirmation of the correct orientation and location of the pTG-6 derived insert. An upstream primer hybridising to the $3^{\prime}$ end of the neo gene $(476 ; 5$ 'CGCCTTCTTGACGAGTTCTTCT-3') and a downstream primer (477; 5'ACCCTTCTGCGAGATGAAACAC-3'), corresponding to the $3^{\prime}$ end of exon 3 in the mouse cystatin $\mathrm{C}$ gene, downstream from the $3^{\prime}$ homologous fragment of the targeting construct (fig 1A), were used for the amplification. The PCR was performed as above with the exceptions that the total volume was $25 \mu \mathrm{l}$ and the amounts of reaction components were decreased proportionally. The reaction conditions were: 12 minutes at $94^{\circ} \mathrm{C}$, followed by 30 cycles of 30 seconds at $94^{\circ} \mathrm{C}, 30$ seconds at $56^{\circ} \mathrm{C}$, and two minutes at $72^{\circ} \mathrm{C}$, with a final incubation at $72^{\circ} \mathrm{C}$ for 12 minutes. PCR products were visualised and size estimated on $1.5 \%$ agarose gels. To purify PCR products, the major PCR band was cut out of the gel and the DNA was extracted using the Jetsorb Gel Extraction Kit (Genomed Gmbh; Bad Oeynhausen, Germany).

Reactions to determine the DNA sequence of the upstream PCR fragment were carried out using the ABI PRISM BigDye Terminator Cycle Sequence kit (Perkin Elmer-Applied Biosystems), using oligonucleotides 5609 or 077 as sequencing primer and $60 \mathrm{ng}$ of purified PCR product in each reaction. The sequencing reactions comprised 30 cycles of 30 seconds at $94^{\circ} \mathrm{C}$ and four minutes at $60^{\circ} \mathrm{C}$ in a Perkin Elmer 2400 thermal cycler. Sequencing reactions were analysed on an ABI Prism 310 genetic analyser (Perkin Elmer-Applied Biosystems).

CYSTATIN C IN MOUSE TISSUES

Heart, lung, liver, spleen, muscle, and brain tissues were isolated from the mutant cystatin $\mathrm{C}$ mice and wild-type mice. The tissues were homogenised with a Teflon glass homogeniser in five volumes of $50 \mathrm{mM}$ Tris/ $\mathrm{HCl}$ buffer, $\mathrm{pH} 7.4$, containing $0.15 \mathrm{M} \mathrm{NaCl}, 5 \mathrm{mM}$ benzamidinium chloride, $10 \mathrm{mM}$ EDTA, and $15 \mathrm{mM} \mathrm{NaN}_{3}$. A dye binding assay was used to measure total protein content in the tissue homogenates as described earlier. ${ }^{36}$ Supernatants from homogenates were diluted to suitable concentrations and applied to a microtitre plate (MaxiSorp; Nunc, Copenhagen, Denmark) coated with specific antibodies against mouse cystatin C. Sample or calibrator solution was added to each well as described previously. ${ }^{36}$ Biotinylated specific antibodies were added directly after application of sample, reacted with streptavidin-horseradish peroxidase conjugate, followed by 2,2-azino-di-(3ethyl-bensothiazolin-sulphonate) and $\mathrm{H}_{2} \mathrm{O}_{2}$. The absorbance was read at $405 \mathrm{~nm}$ in a Titerek multiscan spectrophotometer. For specific measurement of human cystatin $\mathrm{C}$, a similar double sandwich enzyme linked immunosorbent assay (ELISA), but with a monoclonal antibody as detecting reagent, was used. $^{37}$
TUMOUR GROWTH AND METASTASIS ASSAYS

For studies of subcutaneous tumour growth, B16-F10 melanoma cells $\left(1.0 \times 10^{6}\right.$ cells $)$ were suspended in $0.2 \mathrm{ml}$ of sterile PBS and injected subcutaneously into the interscapular area of 8 week old mutant cystatin $\mathrm{C}$ mice and wild-type mice, 10 in each group. Tumour volumes were calculated once a week from three dimensional measurements, using a caliper. After three weeks, all of the mice were killed and the subcutaneous tumours resected and weighed. For the examination of intracerebral tumour growth, the melanoma cells $\left(1.0 \times 10^{4}\right)$ were suspended in $5 \mu \mathrm{l}$ of sterile PBS and injected into the deep white matter of the right cerebral hemisphere (depth of inoculation, $3.5 \mathrm{~mm}$ ), using a hamilton syringe connected to the manipulating arm of the stereotaxic apparatus (David Kopf Instruments, Tujunga, California, USA). Five mutant cystatin C mice and five wild-type mice were used in each group. The mice were killed two weeks later. The brains were fixed in formalin for 10 days and sectioned. The largest tumour diameters within the sections of the brain were used to represent tumour size.

Initial intravenous metastasis assays were carried out at a fixed time point. B16-F10 cells $\left(5.0 \times 10^{5}\right)$ were suspended in $0.1 \mathrm{ml}$ of sterile PBS and injected into the lateral tail vein of 8-10 week old mice. The mice were killed two weeks later and the lungs were inflated and fixed in Bouin's solution, followed by enumeration of metastasis, using a dissecting microscope. A total of 121 mice (57 wild-type and 64 mutant cystatin $\mathrm{C}$ mice) were used for five separate experiments, each containing nine to 13 mice of each genotype. Fourteen lungs from wild-type and four lungs from cystatin C mutant mice contained tumours that were too numerous to count accurately $(>200)$. For statistical analysis of the results, these lungs were given the value of 200 tumours. The median number of pigmented lung metastasis from the five separate experiments was calculated. The data were subjected to statistical analysis, using the Mann-Whitney test.

To study the time course of metastatic spread in the lungs, B16-F10 cells stably transfected with a $\beta$-galactosidase encoding plasmid were used. These cells can be stained blue in situ, thereby facilitating detection and allowing accurate counting of single cells and micrometastases at early time points. In six well plates, $2 \times 10^{5} \mathrm{~B} 16-\mathrm{F} 10$ cells/well were seeded into $2 \mathrm{ml}$ Dulbecco's modified Eagle medium (DMEM) supplemented with pyridoxine (Gibco), and the cells were incubated at $37^{\circ} \mathrm{C}$ in a $5 \% \mathrm{CO}_{2}$ atmosphere until $50-80 \%$ confluency was reached. The cells in each well were transfected using 4-50 $\mathrm{gg}$ lipofectamine (Gibco) mixed with $2 \mu \mathrm{g}$ pSV2neo DNA and $20 \mu \mathrm{g}$ pRSVgal9 DNA (a gift from M Perricaudet, Department of Dermatology, Hospital Bichat, Paris, France) in medium without serum and antibiotics. DNA and lipofectamine were incubated to form a complex at room temperature for 45 minutes before the mixture was added to the cells. After five hours at $37^{\circ} \mathrm{C}$, the medium was replaced, and after 72 hours 
the cells were passaged $1 / 10$ into medium containing G418 (0.3 mg/ml). After approximately 10 days in selective medium, clones were picked using glass capillaries and trypsin, and were allowed to grow up before freezing.

For the time course metastasis experiment, $5.0 \times 10^{5} \beta$-galactosidase transfected cells were injected into cystatin $\mathrm{C}$ mutant and wild-type mice as above. The mice were killed after 15 minutes, 30 minutes, one hour, three hours, 24 hours, three days, seven days, and 14 days. Fifteen mice of each type were injected at each time point. The lungs were inflated and fixed for one hour in $0.1 \mathrm{M}$ PBS, $\mathrm{pH} 7.3$, containing $2 \%$ ( $\mathrm{vol} / \mathrm{vol}$ ) formaldehyde, $0.2 \%$ ( $\mathrm{vol} / \mathrm{vol}$ ) glutaraldehyde, and $1 \mathrm{mM} \mathrm{MgCl}$, and were then rinsed in $0.1 \mathrm{M}$ PBS. The fixed lungs were compressed between glass plates and enumeration of metastatic colonies was performed in six randomly selected areas on the lungs, measuring $6.25 \mathrm{~mm}^{2}$ each (total, $37.5 \mathrm{~mm}^{2}$ ), using a microscope at $40-80 \times$ magnification. Metastatic colonies and cells were counted after staining the fixed tissue overnight with $0.1 \mathrm{M}$ PBS, pH 7.3, containing $0.2 \%$ (wt/vol) X-Gal, $5 \mathrm{mM}$ potassium ferriferrocyanide, and $2 \mathrm{mM}$ $\mathrm{MgCl}_{2} \cdot{ }^{38}$ All pigmented or blue metastatic cells and colonies were counted. In the text below, these are referred to as metastatic colonies, even though many of them were individual or few cells, particularly during the first few time points. The data were analysed as above.

For histopathological evaluation, the $\beta$-galactosidase stained lungs from one mouse in each group of melanoma cell inoculated animals from the time course study were immersion fixed in $10 \%$ buffered formaldehyde. Frontal sections $(4 \mu \mathrm{m})$ were prepared from the largest lung sectional area obtainable and stained with nuclear red.

\section{Results}

GENERATION OF CYSTATIN C NULL MICE

The cystatin $\mathrm{C}$ gene targeting construct used is shown in fig 1A. A segment covering part of the first exon and 5' two thirds of the first intron was removed from the mouse gene and replaced with a neomycin resistance gene cassette containing the phoshoglycerate kinase (PGK) promoter and the neomycin resistance gene. In an attempt to generate mice with their endogenous production of mouse cystatin C replaced by production of the human cystatin C variant causing HCCAA (L68Q-cystatin C), a human mutant cystatin $\mathrm{C}$ cDNA was also included in the construct, downstream of the mouse cystatin $\mathrm{C}$ promoter and upstream of the neomycin resistance gene (fig 1A). The targeting construct was introduced into CCE embryonic stem cells (derived from the 129/Sv strain), which have been widely used for generating knockout mice in several laboratories, including our own. ${ }^{32} 3940$ Four correctly targeted clones were identified. The four clones were injected into C57BL/6J blastocysts. Offspring were checked for chimaerism by visual observation of the coat colour. There was an expected sex bias among the chimaeras from all four clones. Ninety per cent of all the chimaeras were male and only $10 \%$ were female. Male chimaeras were mated to $\mathrm{C} 57 \mathrm{BL} / 6 \mathrm{~J}$ females. Chimaeras from two independently targeted embryonic stem cell clones transmitted the targeted mutation through the germ line. The heterozygotes were intercrossed to obtain mice homozygous for the targeted cystatin $\mathrm{C}$ gene and PCR analysis of their genomic DNA demonstrated the correct structure (deletion of the correct mouse cystatin $\mathrm{C}$ fragment, insertion, and correct orientation of the mutant human cystatin $\mathrm{C}$ cDNA), as shown in fig $1 \mathrm{~B}$.

The expression of mouse and human cystatin $\mathrm{C}$ in various tissues of the homozygous mice was examined by northern blot analysis using mouse or human cystatin $\mathrm{C}$ cDNA as probes, respectively (fig 2). Neither mouse nor human cystatin $\mathrm{C}$ mRNA was detectable in lung, heart, testis, kidney, and brain of the cystatin $\mathrm{C}$ mutant mice, whereas strong signals were obtained for tissues from wild-type mice using the cDNA probe for mouse cystatin C. Approximately $50 \%$ of normal mouse cystatin $\mathrm{C}$ mRNA values were detected in the tissues of heterozygous cystatin $\mathrm{C}$ normal/mutant animals. The cystatin $\mathrm{C}$ protein concentrations in tissue homogenates from cystatin $\mathrm{C}$ mutant and wild-type animals were examined by ELISA using antibodies specific for human and mouse cystatin C (table 1). In complete agreement with the northern blot results, the cystatin $\mathrm{C}$ protein concentrations in the cystatin $\mathrm{C}$ mutant mice were not significantly different from zero, whereas wild-type mice produced normal amounts of mouse cystatin C. Therefore, the "knockin" construct generated mice that were effectively cystatin $\mathrm{C}$ null $\left(\mathrm{Cys}^{-/-}\right)$ with regard to both human and mouse cystatin $\mathrm{C}$, which are referred to as $\mathrm{CysC}^{-/-}$mice throughout this paper.

GENETIC LINKAGE OF THE CYSTATIN C AND AGOUTI LOCI

The distribution of the genotypes in the offspring of the heterozygote matings fitted Mendelian ratios (56 homozygotes, 121 heterozygotes, and 65 wild-type from a total of 242 pups in 26 litters). During analysis of cystatin C genotypes from F2 progeny of heterozygous mice by Southern blot analysis, we found a strong correlation between the cystatin $\mathrm{C}$ genotype and the coat colour of the F2 mice (table 2), indicating strongly that the cystatin $\mathrm{C}$ gene is closely linked to the agouti locus. The calculated distance between the two loci was $4.4 \mathrm{cM}$ (SD, 1.8). Such a close linkage agrees with our previous mapping of the mouse cystatin $\mathrm{C}$ gene (Cst3) to the distal part of chromosome 2, with the locus positioned proximal to Psp and Emv 15 and distal to Snap. ${ }^{4}$

\section{HISTOLOGY}

Cystatin $\mathrm{C}$ null $\left(\mathrm{CysC}^{-/}\right)$mice are born healthy, grow at a normal rate compared with $\mathrm{CysC}^{-/+}$, and wild-type animals, and are fertile. Numerous tissues from $\mathrm{CysC}^{-/-}$mice were examined with haematoxylin and eosin staining, but no apparent histological difference between the $\mathrm{CysC}^{-/-}$and $\mathrm{CysC}^{+/+}$animals was detected up to 6 months of age. Because cystatin $\mathrm{C}$ is found at high concentrations in the 


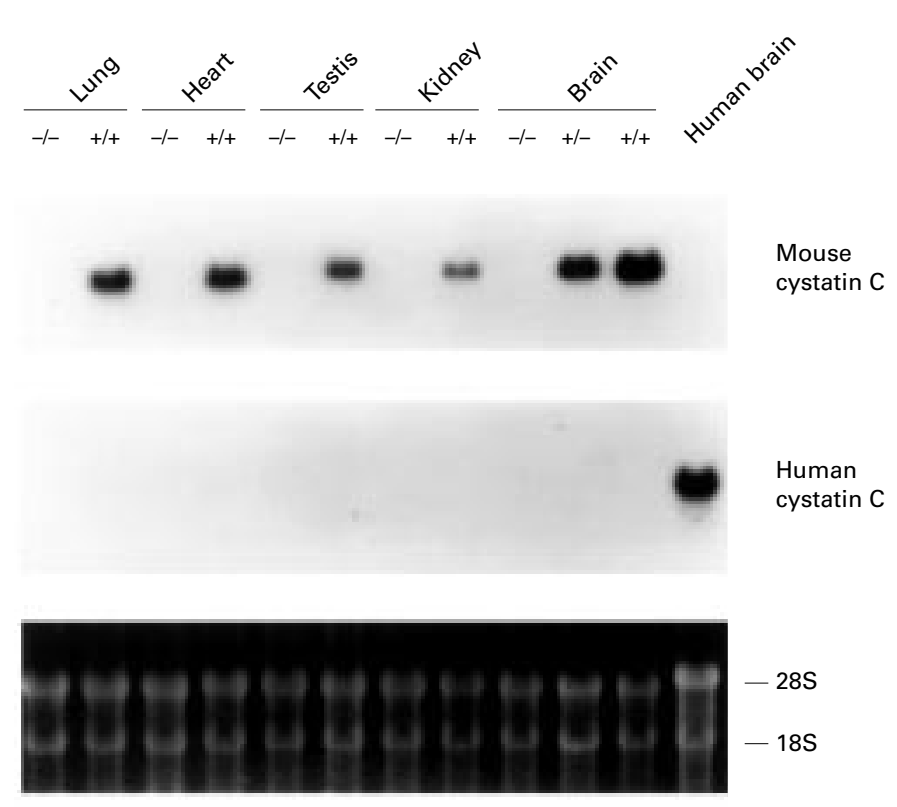

Figure 2 Expression of human and mouse cystatin $C$ genes. Northern blot hybridisation of total RNA (20 $\mu \mathrm{g} / \mathrm{lane})$ from lung, heart, testis, and kidney of homozygous mutant $\left(\mathrm{Cys}_{\mathrm{S}} \mathrm{C}^{-1}\right)$ and wild-type $\left(\mathrm{Cys} \mathrm{C}^{++}\right)$mice, brain of Cys $\mathrm{C}^{-1}$, heterozygous $\left(\mathrm{Cys} \mathrm{C}^{+-}\right)$, and $C y s C^{+++}$mice, and human brain. The blot was probed with mouse cystatin C cDNA (upper panel) and human cystatin C cDNA (middle panel). A picture of the ethidium bromide stained gel before blotting is shown in the lower panel to demonstrate equal loading of the lanes.

CNS, and because we detected some minor behavioural differences between cystatin $\mathrm{C}$ null mice and wild-type animals (the former being slightly hypoactive; results not shown), we examined the CNS in more detail. Sections from cerebrum, cerebellum, brain stem, and the cervical spinal cord were examined by means of haematoxylin and eosin, solochrome and eosin, luxol fast, periodic acid schiff, congo red, and Bitelschowsky staining. No significant difference between cystatin $\mathrm{C}$ null and wildtype animals was seen at this level of analysis.

ALTERED METASTATIC GROWTH IN CYSTATIN C NULL MICE

Because cysteine proteases have been implicated in proteolytic tissue degradation during tumour invasion and metastatic development,
Table 2 Linkage of the cystatin $C$ and agouti loci

\begin{tabular}{lll}
\hline & \multicolumn{2}{l}{ Coat colour (black/total) } \\
\cline { 2 - 3 } CysC genotype & Observed & Expected \\
\hline+++ & $62 / 65$ & $16.2 / 65$ \\
+- & $6 / 121$ & $30.2 / 121$ \\
-- & $0 / 56$ & $14 / 56$ \\
\hline
\end{tabular}

With no linkage between the cystatin $\mathrm{C}$ and agouti loci we would expect to see $25 \%$ of the offspring animals with black coat colour, whereas the remaining $75 \%$ would be agouti, regardless of cystatin $\mathrm{C}(\mathrm{CysC})$ genotypes. The data were used to calculate the distance between the cystatin C (Cst3) and agouti loci to 4.4 $(1.8 \mathrm{cM}) .+/+$, wild-type genotype; +/-, heterozygous genotype; $-/-$, homozygous mutant genotype.

the propensity of melanoma cells to grow and metastasise in $\mathrm{CysC}^{-/-}$mice was examined. The subcutaneous and intracerebral growth rate of the B16-F10 melanoma cell line was comparable in $\mathrm{CysC}^{-/-}$and $\mathrm{CysC}^{+/+}$mice (data not shown). However, after intravenous injection of the melanoma cells, $\mathrm{CysC}^{-/-}$mice had seven times fewer metastatic lung colonies than $\mathrm{CysC}^{+/+}$mice two weeks after injection in an initial experiment using a low power dissecting microscope to count the colonies. The data were summarised from five separate experiments, using a total of $64 \mathrm{CysC}^{-/-}$mice and 57 $\mathrm{CysC}^{+/+}$mice. The median number of metastatic colonies and the standard error of the mean (SEM) were 65 (9.6) and 9.0 (6.2) in the $\mathrm{CysC}^{+++}$and $\mathrm{CysC}^{-/-}$mice, respectively. The difference between the groups was highly significant in a Mann-Whitney test $(\mathrm{p}<0.0001)$. Light microscopic examination of the lungs did not reveal histological differences in the pulmonary structure or the growth patterns of the metastasis between the two groups. Pulmonary micrometastases were seen in both groups and, in some cases, they were detected in $\mathrm{CysC}^{-/-}$mice without any macroscopic metastasis.

However, because the dissecting microscope did not detect micrometastases or single cells, this method could not be used to assess seeding efficiency in the lungs. To elucidate whether the reduced metastatic colony numbers in the $\mathrm{CysC}^{-/-}$mice seen two weeks after injection of the melanoma cells was a result of decreased growth in the lung and/or an inhibition of the seeding of cells in the lung, a time course metastasis experiment was performed. For this,

Table 1 Measurement of mouse and human cystatin $C$

\begin{tabular}{|c|c|c|c|c|}
\hline & \multicolumn{2}{|l|}{ Cys $C^{+/+}$mice } & \multicolumn{2}{|l|}{ Cys $C^{-/-}$mice } \\
\hline & Mouse cystatin $C$ & Human cystatin $C$ & Mouse cystatin $C$ & Human cystatin $C$ \\
\hline \multicolumn{5}{|c|}{ Tissue homogenates (ng/mg protein) } \\
\hline Heart & $48(4.6)$ & $<0.9$ & $<0.3$ & $<0.9$ \\
\hline Lung & $40(2.4)$ & $<0.9$ & $<0.3$ & $<0.9$ \\
\hline Spleen & $34(2.8)$ & $<0.9$ & $<0.3$ & $<0.9$ \\
\hline Muscle & $49(4.9)$ & $<0.9$ & $<0.3$ & $<0.9$ \\
\hline Brain & $280(11)$ & $<0.9$ & $<0.3$ & $<0.9$ \\
\hline Liver & $14(1.2)$ & $<0.9$ & $<0.3$ & $<0.9$ \\
\hline \multicolumn{5}{|c|}{ Blood at metastasis experiment $(\mathrm{ng} / \mathrm{ml})$} \\
\hline Uninjected & 818 & $<0.8$ & $<0.5$ & $<0.8$ \\
\hline 15 min post-inj. & 710 & $<0.8$ & $<0.5$ & $<0.8$ \\
\hline $24 \mathrm{~h}$ post-inj. & 691 & $<0.8$ & $<0.5$ & $<0.8$ \\
\hline 2 weeks post-inj. & 902 & $<0.8$ & $<0.5$ & $<0.8$ \\
\hline
\end{tabular}

Measurements of mouse and human cystatin $\mathrm{C}$ in mouse tissues and mouse blood plasma were performed by enzyme linked immunosorbent assays based on specific antibodies against mouse and human cystatin C. Total protein concentrations ( $\mathrm{mg} / \mathrm{ml}) \mathrm{in}$ corresponding samples were determined by means of a dye binding assay. For tissue homogenates, the cystatin C concentrations were related to total protein contents. Mean (SEM) values were calculated from six animals. Blood plasma was collected from homozygous mutant $\left(\mathrm{CysC}^{-/}\right)$mice injected with $\mathrm{B} 16-\mathrm{F} 10$ cells at different timepoints after injection (post-inj.), and from uninjected mice. Results from the measurement of cystatin $\mathrm{C}$ in pooled blood from two animals are shown. Cys $\mathrm{C}^{+/+}$, wild-type genotype. 


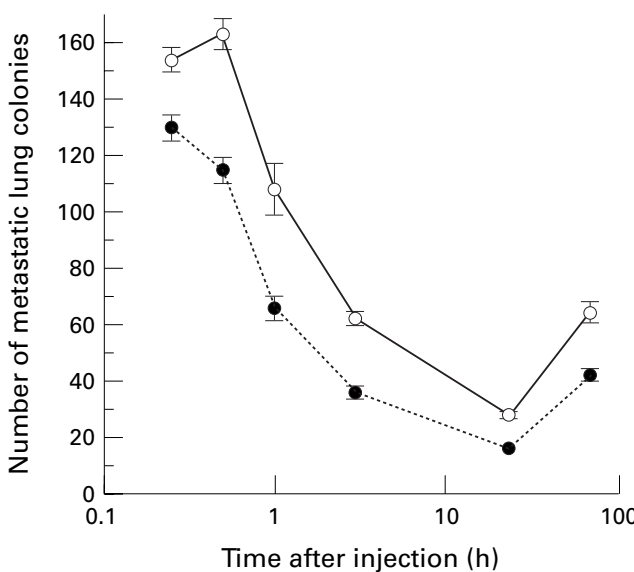

Figure 3 Metastatic spread in homozygous mutant (Cys $C^{-1-}$ ) mice. The number of metastatic lung colonies counted in wild-type (Cys $\left.C^{+/+}\right)$and $C y s C^{-/-}$mice 15 minutes, 30 minutes, one hour, three hours, 24 hours, and three days after injections of $\beta$-galactosidase transfected B16-F10 melanoma cells. The data points represent mean values for $15 \mathrm{Cys} \mathrm{C}^{+/+}$mice (open symbols) and $15 \mathrm{Cys} \mathrm{C}^{-/}$ mice (closed symbols) at each time point, with the standard error of the mean (SEM) shown as vertical bars when larger than the radius of the symbol. At statistical evaluation of the data, it was seen that the differences between the Cys $C^{++}$mice and $C y s C^{-1-}$ mice were significant at all time points: 15 minutes, $p=0.0003 ; 30$ minutes, $p<0.0001$; one hour, $p<0.0001$; three hours,

$p<0.0001 ; 24$ hours, $p<0.0001$; three days, $p=0.0002$.

$\beta$-galactosidase transfected B16-F10 cells were used, to allow counting of individual melanoma cells and micrometastases at the early time points. In total, 120 mice of each type were analysed at times ranging from 15 minutes to 96 hours after injection. Counting of melanoma cells and lung colonies in these animals, using magnification that allows detection of micrometastases and single melanoma
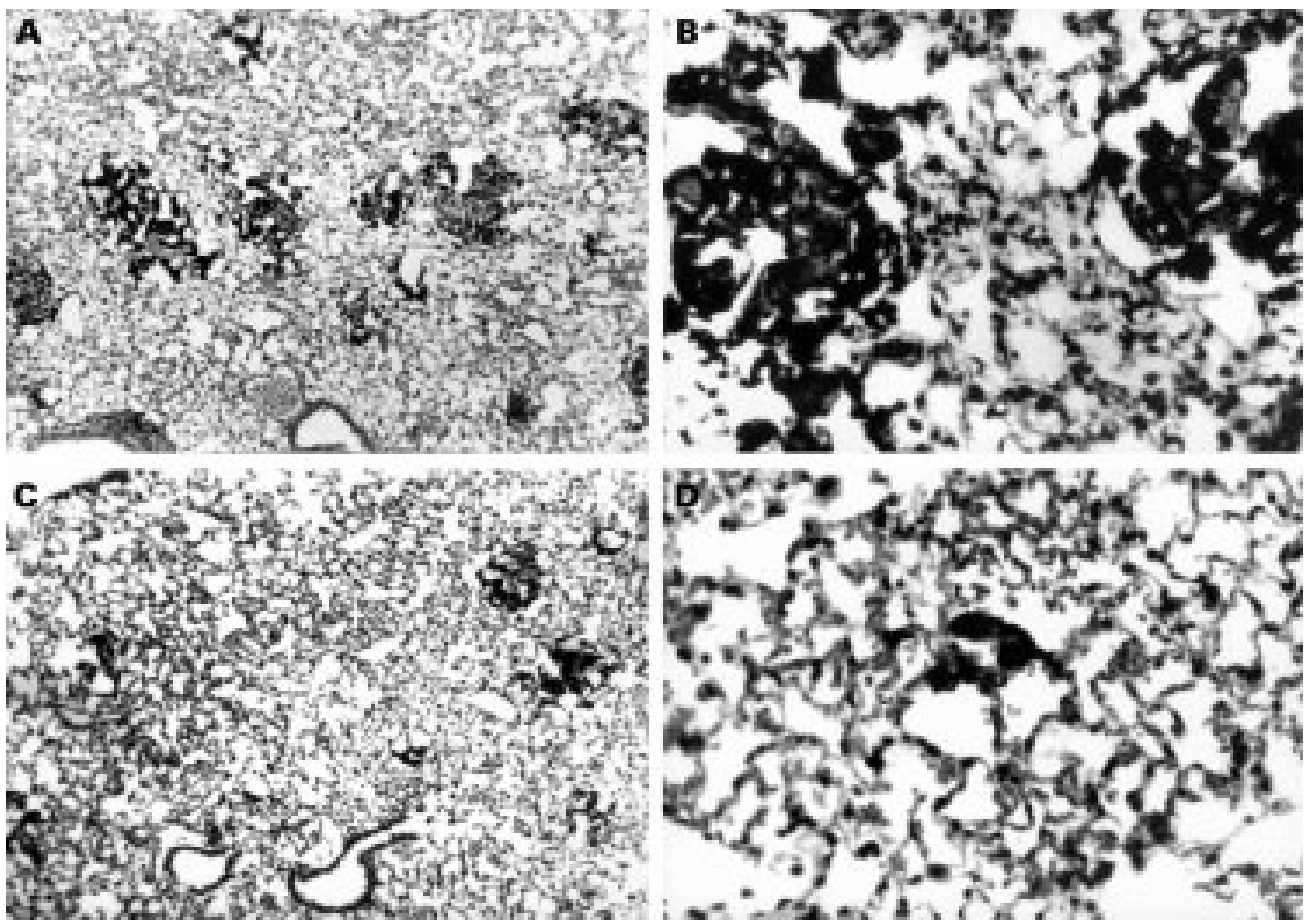

Figure 4 Histopathological examination of mouse lungs. Histopathological evaluations were performed on lungs from wild-type $\left(C y s C^{+/+}\right)$and homozygous mutant $\left(C y s C^{-1}\right)$ mice after tail vein injection of B16-F10 melanoma cells. Sections from lungs of $C y s C^{+/+}(A$ and $B)$ and $C y s C^{-/-}(C$ and $D)$ mice two weeks after tumour cell inoculation are shown using a

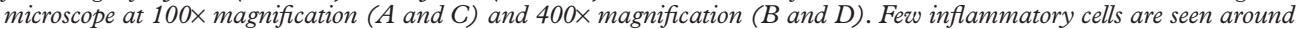
the tumour colonies. cells in the $\mathrm{CysC}^{-/-}$mice after as short a time as 15 minutes (fig 3). The number of melanoma colonies decreased in both types of mice during the first 24 hours, after which the number of detectable colonies increased. This pattern seems to correlate with an initial phase when the melanoma cells attach in the lung capillarimmune system during the first day, before they have passed the endothelial cell layer of the vessels to start forming lung colonies. ${ }^{41} \mathrm{At}$ all time points, the $\mathrm{CysC}^{-/-}$mice showed significantly fewer metastatic cells/colonies than the wild-type mice (see legend to fig 3), although the difference was much smaller than that observed when metastatic foci on the surface of the lungs were enumerated at 14 days, using a dissecting microscope. The significant difference observed at the early time points suggests that the seeding efficiency of the melanoma cells is decreased in the lungs of $\mathrm{CysC}^{-/-}$mice. Histopathological examination revealed multiple tumour colonies one week and especially two weeks after injection of the melanoma cells. The colonies were spread throughout the lung tissue, and those of the $\mathrm{CysC}^{+/+}$group exceeded those of the $\mathrm{CysC}^{-/-}$ group both in number and size (fig 4). The colonies seemed rather randomly distributed, although some were localised in the vicinity of blood vessels. Few macrophages and other inflammatory cells were found around the colonies.

The observed decreased metastatic spread in the lungs of $\mathrm{CysC}^{-/}$mice was somewhat surprising, given that cysteine proteases produced and secreted by tumour cells are thought cells, demonstrated a decreased number of ies, are washed away, or defeated by the 
to promote invasiveness by degradation of connective tissue components, and to thereby increase the metastatic potential of the cells. ${ }^{25}$ In support of this idea, it has been reported recently that transfection of the same B16-F10 cell line used in our experiments with a cystatin $\mathrm{C}$ expression plasmid resulted in inhibited motility and in vitro invasiveness of the cells, which was attributed to overexpression of cystatin C gene. ${ }^{42}$ This prompted us to study the melanoma cell system in more detail. The B16-F10 cells secreted $25 \mathrm{ng} / \mathrm{ml}$ of mouse cystatin C when cultured for 24 hours in DMEM containing $10 \%$ fetal calf serum at an initial seeding of approximately $0.2 \times 10^{6}$ cells/ $\mathrm{ml}$. Tail vein injection of $5 \times 10^{5}$ cells (the number used in all metastasis experiments) resulted in neither measureable amounts of cystatin $\mathrm{C}$ in the circulation of $\mathrm{CysC}^{-/-}$mice nor in a significant increase in circulating cystatin $\mathrm{C}$ in the $\mathrm{CysC}^{+/+}$animals (table 1 ).

\section{Discussion}

Cystatin C null mice appear normal, they are fertile, and histopathological examination has so far not revealed any abnormalities. Therefore, the clinical phenotype resulting from this gene knockout is mild. It is surprising that the phenotype is not more severe because cystatin C is produced in most, if not all, cells in the animal. ${ }^{36}$ The results indicate that other cysteine protease inhibitors might be able to take over most functions of cystatin $\mathrm{C}$, and this redundancy might explain the subtle phenotypic changes that we found.

The subcutaneous and cerebral growth rates of injected B16-F10 melanoma cells were comparable in the $\mathrm{CysC}^{-/-}$mice and wild-type mice, whereas the number of experimental lung metastases were seven times fewer in the $\mathrm{CysC}^{-/-}$mice when examined by means of a dissecting microscope at 14 days after tail vein injection. Very small metastatic colonies in the lungs were observed in some of the mutant mice. This seemed to indicate that tumour growth in the $\mathrm{CysC}^{-/-}$lungs was inhibited. The decrease in the lung colonising potential of $\mathrm{B} 16-\mathrm{F} 10$ melanoma cells in the $\mathrm{CysC}^{-/-}$mice is intriguing, especially because subcutaneous and intracerebral tumour growth was not inhibited. We are not aware of any reports on the effects of cystatin $\mathrm{C}$ on the replication of melanoma cells, but the inhibitor has been shown to stimulate proliferation of glomerular rat mesangial cells, ${ }^{43}$ and the chicken homologue to cystatin $\mathrm{C}$ has been reported to stimulate the growth of mouse Swiss 3T3 fibroblasts. ${ }^{44}$ This prompted us to perform more detailed time course studies to ask whether alterations in tumour growth alone, alterations in seeding potential of B16-F10 melanoma cells to the lung, or both, could explain the fewer metastatic colonies in the mutant mice.

Ultrastructural studies of the metastatic cascade in the lungs after intravenous injection of the B16-F10 melanoma cell line have been described in detail elsewhere..$^{45}$ Tumour cells are arrested in the lung microvasculature by adhering to the plasma membrane of endothe- lial cells and there is an immediate (within a few minutes) development of a platelet thrombus in association with the tumour cells. The tumour cells start penetrating vascular endothelial cell junctions within a few hours and intravascular mitosis of tumour cells starts within 24 hours. Finally, the expanding metastatic foci penetrate the subendothelial matrix after two to three days.

To evaluate the initial stages of lung colonisation, we used $\beta$-galactosidase labelled B16-F10 cells. This allowed us to enumerate single tumour cells and micrometastases throughout the lungs. Our time course study clearly demonstrated that adhesion and seeding of tumour cells in the lungs was decreased in the $\mathrm{CysC}^{-/-}$mice. Even as early as the 15 minute time point, the numbers of melanoma cells detected in the lung were significantly higher in the wild-type mice than the mutant mice. When small micrometastases and individual tumour cells were counted in the time course study, a smaller difference was seen between mutant and control mice than when a low power dissecting microscope was used, which detected only the larger metastatic colonies. We conclude that both seeding of metastatic cells to the lung and their growth in the lung parenchyma after extravasation were inhibited in the $\mathrm{CysC}^{-/-}$mice.

The reasons for reduced seeding in the mice lacking cystatin $\mathrm{C}$ are unknown, but could be the consequence of a proteolytic event caused by a cysteine protease during the first 24 hours after injection of the melanoma cells. Cystatin $\mathrm{C}$ is a major constitutive secreted product of alveolar macrophages in humans. ${ }^{47}$ Metastatic tumour cells infiltrating target organs frequently elicit a local inflammatory response, including infiltration of local macrophages. The reduced number of metastases detected in $\mathrm{CysC}^{-/-}$mice raises the question of whether an increased release of active cathepsin B from pulmonary macrophages ${ }^{47}$ is responsible for reduced tumour cell seeding and/or growth in the lungs, although we did not find an increased number of macrophages in the metastatic lungs of $\mathrm{CysC}^{-/-}$mice compared with controls. Alternatively, increased proteolysis in the lung might lead to reduced local concentrations of growth factors that are important for growth of the melanoma cells. Therefore, these cystatin $\mathrm{C}$ null mice might provide an important animal model for studies of the role of cystatin $\mathrm{C}$ in metastatic development.

In our study, we originally attempted to express human HCCAA related cystatin C mutant cDNA by generating a knockin construct. No expression of the human cDNA was detected. Although the reason for this is unknown, it is possible that measurable amounts of human cystatin C RNA were not generated because we did not specifically add splice sites and introns downstream from the cDNA, ${ }^{48}$ and were relying on the second intron and polyadenylylation signal of the endogenous mouse cystatin $\mathrm{C}$ gene.

In conclusion, we have generated cystatin $\mathrm{C}$ null mice that show a very mild clinical phenotype. These mice will be useful for future stud- 
ies to determine more closely the different biological functions of cystatin C. In particular, the decreased pulmonary seeding of metastatic melanoma cells observed here indicates that the cystatin $\mathrm{C}$ null mice might become an important animal model for metastasis studies.

C-G Huh and K Håkansson contributed equally to the study. This study was supported by grant B96-19X-11620-01A from the Medical Research Council, Sweden and grant 3652-B9703XAC from Cancerfonden, Sweden, both to SK. This project was also supported by a grant from the network for inflammation research funded by the Swedish Foundation for Strategic Research; the Swedish Medical Research Council projects numbers 05196 and 09915; and A Österlund's, A Påhlsson's, and G and J Kock's Foundations. We would like to thank Dr CA Kozak for linkage calculations, Dr K Suzuki and Dr JM Ward for pathology studies, and Dr AB Kulkarni for general advice. We would also like to thank the late Dr O Jensson for help in initiating this study and we would like to dedicate this paper to his memory.

1 Abrahamson M, Barrett AJ, Salvesen G, et al. Isolation of six cysteine proteinase inhibitors from human urine. Their physicochemical and enzyme kinetic properties and concentrations in biological fluids. $\mathfrak{f}$ Biol Chem concentrations in

2 Barrett AJ, Fritz H, Grubb A, et al. Nomenclature and classification of the proteins homologous with the cysteineproteinase inhibitor chicken cystatin. Biochem 7 1986;236: protein

3 Abrahamson M, Olafsson I, Palsdottir A, et al. Structure and expression of the human cystatin C gene. Biochem f 1990; 268: $287-94$.

4 Huh C, Nagle JW, Kozak CA, et al. Structural organization, expression and chromosomal mapping of the mouse cystatin-C-encoding gene (Cst3). Gene 1995;152:221-6.

5 Löfberg H, Grubb AO. Quantitation of gamma-trace in human biological fluids: indications for production in the central nervous system. Scand 7 Clin Lab Invest 1979;39: 619-26.

6 Delaissé JM, Eeckhout Y, Vaes G. In vivo and in vitro evidence for the involvement of cysteine proteinases in bone resorption. Biochem Biophys Res Commun 1984;125:441-7.

7 Lesorption. Biochem Biophys Res Commun 1984;125:441-7. nase inhibitor, inhibits bone resorption in vitro stimulated by parathyroid hormone and parathyroid hormone-related by parathyroid hormone and parathyroid hormone-related

8 Marks N, Berg MJ, Benuck M. Preferential action of rat Marks N, Berg MJ, Benuck M. Preferential action of rat
brain cathepsin B as a peptidyl dipeptidase converting proopioid oligopeptides. Arch Biochem Biophys 1986;249:48999.

9 Leung-Tack J, Tavera C, Martinez J, et al. Neutrophil chemotactic activity is modulated by human cystatin $\mathrm{C}$, an inhibito of cysteine proteases. Inflammation 1990;14:247-58.

10 Leung-Tack J, Tavera C, Gensac MC, et al. Modulation of phagocytosis-associated respiratory burst by human cystatin C: role of the N-terminal tetrapeptide Lys-Pro-Pro-Arg. Exp Cell Res 1990;188:16-22.

11 Naito Y, Sasaki M, Umemoto T, et al. Bactericidal effect of rat cystatin $\mathrm{S}$ on an oral bacterium Porphyromonas gingivalis. Comp Biochem Physiol C Pharmacol Toxicol Endocrinol 1995;110:71-5.

12 Kondo H, Ijiri S, Abe $\mathrm{K}$, et al. Inhibitory effect of oryzacystatins and a truncation mutant on the replication oryzacystatins and a truncation mutant on the replication of poliovir

13 Korant BD, Brizin J, Turk V. Cystatin, a protein inhibitor of cysteine proteases alters viral protein cleavage in infected human cells. Biochem Biophys Res Commun 1985;127:10726.

14 Aoki H, Akaike T, Abe K, et al. Antiviral effect of oryzacystatin, a proteinase inhibitor in rice, against herpe simplex virus type 1 in vitro and in vivo. Antimicrob Agent Chemother 1995;39:846-9.

15 Luaces AL, Barrett AJ. Affinity purification and biochemical characterization of histolysin, the major cysteine proteinase of Entamoeba histolytica. Biochem f 1988;250:903-9.

16 Mottram JC, North MJ, Barry JD, et al. A cysteine proteinase cDNA from Trypanosoma brucei predicts an enzyme with an unusual C-terminal extension. FEBS Lett 1989; 258:211-15.

17 Lerner U, Johansson L, Ransjö M, et al. Cystatin C, an inhibitor of bone resorption produced by osteoblasts. Acta Physiol Scand 1997;161:81-92.

18 Björck L, Grubb A, Kjellen L. Cystatin C, a human proteinase inhibitor, blocks replication of herpes simplex virus. $\mathcal{F}$ Virol 1990;64:941-3.

19 Collins AR, Grubb A. Inhibitory effects of recombinant human cystatin $\mathrm{C}$ on human coronaviruses. Antimicrob Agents Chemother 1991;35:2444-6.

20 Jensson O, Gudmundsson G, Arnason A, et al. Hereditary cystatin C (gamma-trace) amyloid angiopathy of the CNS causing cerebral hemorrhage. Acta Neurol Scand 1987;76: $102-14$. 21 Palsdottir A, Abrahamson M, Thorsteinsson L, et al. Muta-
tion in cystatin C gene causes hereditary brain haemorhage. Lancet 1988;2:603-4.

22 Abrahamson $\mathrm{M}$, Jonsdottir S, Olafsson I, et al. Hereditary cystatin C amyloid angiopathy: identification of the disease-causing mutation and specific diagnosis by polymerase chain reaction based analysis. Hum Genet 1992;89:377-80.

23 Schnittger S, Rao VV, Abrahamson M, et al. Cystatin C (CST3), the candidate gene for hereditary cystatin C amyloid angiopathy (HCCAA), and other members of the cystatin gene family are clustered on chromosome 20p11.2. Genomics 1993;16:50-5.

24 Pennacchio LA, Lehesjoki AE, Stone NE, et al. Mutations in the gene encoding cystatin B in progressive myoclonus epilepsy (EPM1). Science 1996;271:1731-4.

25 Sloane BF, Moin K, Krepela E, et al. Cathepsin B and its endogenous inhibitors: the role in tumour malignancy. Cancer Metastasis Rev 1990;9:333-52.

26 Sloane BF, Honn KV, Sadler JG, et al. Cathepsin B activity in B16 melanoma cells: a possible marker for metastatic potential. Cancer Res 1982;42:980-6.

27 Sloane BF, Dunn JR, Honn KV. Lysosomal cathepsin B: correlation with metastatic potential. Science 1981;212: 1151-3.

28 Chambers AF, Colella R, Denhardt DT, et al. Increased expression of cathepsins $\mathrm{L}$ and $\mathrm{B}$ and decreased activity of their inhibitors in metastatic, ras-transformed NIH 3T3 cells. Mol Carcinog 1992;5:238-45.

29 Denhardt DT, Greenberg AH, Egan SE, et al. Cysteine proteinase cathepsin L expression correlates closely with the metastatic potential of H-ras-transformed murine fibroblasts. Oncogene 1987;2:55-9.

30 Sambrook J, Fritsch EF, Maniatis T. Molecular cloning: a laboratory manual. 2nd ed. New York: Cold Spring Harbor, 1989.

31 Hogan B, Beddington R, Constantini F, et al. Manipulating the mouse embryo: a laboratory manual. New York: Cold Spring Harbor, 1994.

32 Tybulewicz VL, Crawford CE, Jackson PK, et al. Neonatal lethality and lymphopenia in mice with a homozygous disruption of the c-abl proto-oncogene. Cell 1991;65:115363.

33 Robertson EJ. Embryo derived stem cell lines. In: Teratocarcinomas and embryonic stem cells: a practical approach. Oxford: IRL, 1987:71-112

34 Laird PW, Zijderveld A, Linders K, et al. Simplified mammalian DNA isolation procedure. Nucleic Acids Res 1991;19:4293.

35 Miller SA, Dykes DD, Polesky HF. A simple salting out procedure for extracting DNA from human nucleated cells. Nucleic Acids Res 1988;16:1215.

36 Håkansson K, Huh C, Grubb A, et al. Mouse and rat cystatin C: Escherichia coli production, characterization and tissue distribution. Comp Biochem Physiol B Biochem Mol Biol 1996;114:303-11.

37 Olafsson I, Löfberg H, Abrahamson M, et al. Production, characterization and use of monoclonal antibodies against the major extracellular human cysteine proteinase inhibitors cystatin C and kininogen. Scand $\mathcal{F}$ Clin Lab Invest 1988;48:573-82.

38 Miller J. Experiments in molecular genetics. New York: Cold Spring Harbor, 1972.

39 Robertson E, Bradley A, Kuehn M, et al. Germ-line transmission of genes introduced into cultured pluripotential cells by retroviral vector. Nature 1986;323:445-8.

40 Kulkarni AB, Huh CG, Becker D, et al. Transforming growth factor beta 1 null mutation in mice causes excessive inflammatory response and early death. Proc Natl Acad Sci USA 1993;90:770-4.

41 Liotta LA, Guirguis R, Stracke M. Biology of melanoma invasion and metastasis. Pigment Cell Res 1987;1:5-15.

42 Sexton PS, Cox JL. Inhibition of motility and invasion of B16 melanoma by the overexpression of cystatin C. Melanoma Res 1997;7:97-101.

43 Tavera C, Leung-Tack J, Prevot D, et al. Cystatin C secretion by rat glomerular mesangial cells: autocrine loop for in vitro growth-promoting activity. Biochem Biophys Res Commun 1992;182:1082-8.

44 Sun Q. Growth stimulation of 3T3 fibroblasts by cystatin. Exp Cell Res 1989;180:150-60.

45 Crissman JD, Hatfield J, Schaldenbrand M, et al. Arrest and extravasation of B16 amelanotic melanoma in murine ungs. A light and electron microscopic study. Lab Invest 1985;53:470-8

46 Crissman JD, Hatfield JS, Menter DG, et al. Morphological study of the interaction of intravascular tumour cells with endothelial cells and subendothelial matrix. Cancer Res 1988;48:4065-72.

47 Chapman HA, Jr, Reilly JJ, Jr, Yee R, et al. Identification of cystatin $\mathrm{C}$, a cysteine proteinase inhibitor, as a major secretory product of human alveolar macrophages in vitro. Am Rev Respir Dis 1990;141:698-705.

48 Brinster RL, Allen JM, Behringer RR, et al. Introns increase transcriptional efficiency in transgenic mice. Proc Natl Acad Sci USA 1988;85:836-40. 